\title{
SOLID STATE SYNTHESIS OF MICRO AND NANOSTRUCTURED METAL OXIDES USING ORGANOMETALLIC-POLYMERS PRECURSORS
}

\author{
CARLOS DÍAZ ${ }^{*}$, MARÍA LUISA VALENZUELA ${ }^{* b}$, GABINO CARRIEDO ${ }^{c}$ AND NICOLAS YUTRONIC ${ }^{a}$ \\ aDepartamento de Química, Facultad de Ciencias, Universidad de Chile, Las Palmeras 3425, Ñuñoa, Casilla 653, Santiago, Chile. \\ ${ }^{b}$ Universidad Autónoma de Chile, Dirección de investigación y Postgrado, Carlos Antúnez 1920, Santiago, Chile. \\ c Departamento de Química Orgánica e Inorgánica. Facultad de Química. Universidad de Oviedo. C/Julián Clavería S/N. Oviedo 33071. España.
}

\section{ABSTRACT}

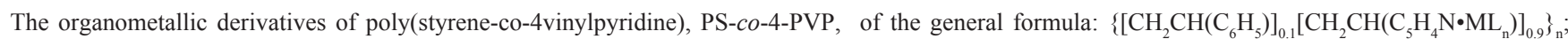
$\mathrm{ML}_{\mathrm{n}} \mathrm{W}(\mathrm{CO})_{5},(1), \mathrm{CpRu}\left(\mathrm{PPh}_{3}\right)_{2}(2), \mathrm{CpFe}(\mathrm{dppe})(3), \mathrm{Cp}_{2} \mathrm{TiCl}(4)$ and $\mathrm{CH}_{3}-\mathrm{C}_{5} \mathrm{H}_{4}-\mathrm{Mn}(\mathrm{CO})_{2}$ (5) were prepared from the respective organometallic and the copolymer $\left\{\left[\mathrm{CH}_{2} \mathrm{CH}\left(\mathrm{C}_{6} \mathrm{H}_{5}\right)\right]_{0.1}\left[\mathrm{CH}_{2} \mathrm{CH}\left(\mathrm{C}_{5} \mathrm{H}_{4} \mathrm{~N}\right]_{0.9}\right\}_{\mathrm{n}}\right.$. The solid state pyrolysis of these derivatives under air and at $800{ }^{\circ} \mathrm{C}$ give rise to micro and nanostructured powder metal oxides $\mathrm{WO}_{3}, \mathrm{RuO}_{2}, \mathrm{TiO}_{2} \mathrm{Mn}_{2} \mathrm{O}_{3}$ and the iron (III) phosphate $(\mathrm{FePO})$ in the case of the iron precursor. The pyrolytic products were characterized by X-ray diffraction (XRD), scanning electron microscopy (SEM), transmission electron microscopy (TEM), and energy dispersive X-ray scattering (EDX) and infrared spectroscopy (IR). From the TG (thermal gravimetric) and DSC (differential scanning calorimetry) data a possible mechanism for the formation of the solid nanostructured materials is discussed.

The method appears to be a reliable and general way to obtain nanostructured metal oxide in solid-state which could be potentially and easily incorporated in solid-state electronics, catalysts and sensor devices.

Keywords: Micro and nanostructured materials, metal oxide, solid-state, nanoparticles.

\section{INTRODUCTION}

In recent years intensive research attention has been increase draw in an effort to synthesize micro- and nanomateriales for their fundamental size, morphology-dependent magnetic properties and many important technological applications which are derived from their low dimensionality combined with the quantum confinement effect. ${ }^{1-3}$ Metal oxides, in particular, have attracted great interest for their applications as anode materials for lithium batteries, ${ }^{4}$, ${ }^{5}$ catalysis, ${ }^{5-7}$ sensors, ${ }^{8}$ solar cells, ${ }^{9}$ solid-state transistors ${ }^{10}$ and metal ion removal. ${ }^{11}$ Although several solution methods to prepare nanostructured metal oxides have been reported ${ }^{12-16}$ few solid-state route have appeared. ${ }^{17}$ The ability to rationally prepare metallic and metal oxide nanoparticles stems from the exploring methods for alternative nanoscale metal deposition in solidstate nanoelectronics and nanotechnology ${ }^{18-21}$ and the benefit of being able to deposit both metals and dielectric or semiconducting oxides, both from the same base route. Issues including limitations on good mechanical and thermal stability of nanoscale metals have been found to be related to certain deposition methods for these metals.

Poly(styrene-co-4vinylpyridine) (see figure 1) is an interesting copolymer due to the vinylpyridine block which binds metal ions and the styrene groups which then form shells, leading to stable macromolecular complexes. ${ }^{22-26}$

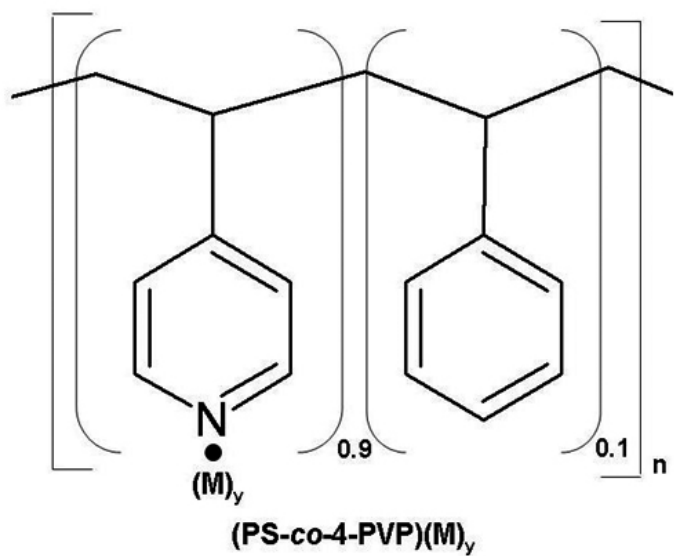

Figure 1: Formula of the precursor $\left[\mathrm{CH}_{2} \mathrm{CH}\left(\mathrm{C}_{6} \mathrm{H}_{5}\right)\right]_{0,1}\left[\mathrm{CH}_{2} \mathrm{CH}\left(\mathrm{C}_{5} \mathrm{H}_{4} \mathrm{~N} \cdot \mathrm{M}\right.\right.$ $\left.\left.\left.\mathrm{L}_{\mathrm{n}}\right)\right]_{0.9}\right\}_{\mathrm{n}}$.
Although the PS-co-4-PVP has been used in solution as template/stabilizer of metals and other solutions, ${ }^{27-29}$ no reported experimental data are available concerning its use as solid-state template/stabilizer of nanoparticles. In this work we report the first example of Poly(styrene-co-4vinylpyridine as solidstate template for the formation of metallic oxides micro and nanoparticles.

In this work we descried a useful and general solid-state methods to prepare metal oxides micro and nanoparticles from the pyrolysis of the macromolecular organometallic-complexes $\left\{\left[\mathrm{CH}_{2} \mathrm{CH}\left(\mathrm{C}_{6} \mathrm{H}_{5}\right)\right] 0.1\left[\mathrm{CH}_{2} \mathrm{CH}\left(\mathrm{C}_{5} \mathrm{H}_{4} \mathrm{~N}\right.\right.\right.$ -MLn) $\left.]_{0 .}\right\} \mathrm{n} ; \mathrm{MLn}=\mathrm{W}(\mathrm{CO})_{5}, \mathrm{CpRu}\left(\mathrm{PPh}_{3}\right)_{2}, \mathrm{CpFe}(\mathrm{dppe}), \mathrm{Cp}_{2} \mathrm{TiCl}$ and $\mathrm{CH}_{3}$ $\mathrm{C}_{5} \mathrm{H}_{4}-\mathrm{Mn}(\mathrm{CO})_{2}$.

The poly(styrene-co-4vinylpyridine) co-polymer can therefore act as a solid-state template which after combustion goes away as volatile products. Although isolated method to prepare nanostructured metal oxides have been reported ${ }^{17}$ no general solid-state way have appeared. The here reported method constitute a easy and general way toward micro and nanostructured metal oxide.

In the last year, organometallic derivatives of oligo and polyphosphazenes have also shown to be useful solid-state precursors of $\mathrm{M}^{\circ}, \mathrm{M}_{\mathrm{x}} \mathrm{O}_{\mathrm{y}}$ and $\mathrm{M}_{\mathrm{x}} \mathrm{P}_{\mathrm{y}} \mathrm{O}$ nanostructured materials..$^{30-39}$ Solid-state pyrolysis of organometallic derivatives at $800^{\circ} \mathrm{C}$ affords metallic nanostructures.

However, due to the presence of phosphorus in the polymeric chain, the nanostructured materials usually involve phosphates and/or pyrophosphates metallic phases. Therefore, if we want to obtain pure metal oxides or metal nanoparticles, a polymer not containing phosphorus within the polymeric chain could be desirable. It is expected that phosphorus-less organic polymers have the potential to be good solid-state template of metallic and organometallicmacromolecular complexes during their pyrolysis. The aim of this work is to prepare pure metal oxides nanoparticles from the solid-sate pyrolysis of the macromolecular organometallic-complexes $\left\{\left[\mathrm{CH}_{2} \mathrm{CH}\left(\mathrm{C}_{6} \mathrm{H}_{5}\right)\right]_{0},\left[\mathrm{CH}_{2} \mathrm{CH}\left(\mathrm{C}_{5} \mathrm{H}\right.\right.\right.$ $\left.\left.\left.{ }_{4} \mathrm{~N} \cdot \mathrm{ML}_{\mathrm{n}}\right)\right]_{00}\right\}_{\mathrm{n}}, \mathrm{ML}_{\mathrm{n}}=\mathrm{W}(\mathrm{CO})_{5}, \mathrm{CpRu}\left(\mathrm{PPh}_{3}\right)_{2}, \mathrm{CpFe}(\mathrm{dppe}), \mathrm{Cp}_{2} \mathrm{TiCl}$ and $\mathrm{CH}_{3}-$ $\left.\mathrm{C}_{5} \mathrm{H}_{4}-\mathrm{Mn}(\mathrm{CO})\right)_{2}$. It is thus anticipated that in the precursors containing phosphorus atoms (as auxiliary ligands or as counterions), metal phosphates or metal pyrophosphates nanoparticles could eventually also be obtained.

The poly(styrene-co-4vinylpyridine) co-polymer can therefore acts as a solid-state template which after combustion goes away as volatile products.

\section{EXPERIMENTAL}

\section{Physical-Chemical Measurements}

All reactions were carried out under dinitrogen using standard Schlenk 
techniques. IR spectra were recorded on an FT-IR Perkin-Elmer Spectrum BX spectrophotometer. Solvents were dried and purified using standard procedures. The polymer $\left\{\left[\mathrm{CH}_{2} \mathrm{CH}\left(\mathrm{C}_{6} \mathrm{H}_{5}\right)\right]_{0}\left[\mathrm{CH}_{2} \mathrm{CH}\left(\mathrm{C}_{5} \mathrm{H}_{4} \mathrm{~N}\right]_{0}\right\}, \mathrm{W}(\mathrm{CO})_{6}\right.$, $\mathrm{CpRu}\left(\mathrm{PPh}_{3}\right)_{2} \mathrm{Cl}, \mathrm{Cp}_{2} \mathrm{TiCl}_{2}$ and $\mathrm{CH}_{3}-\mathrm{C}_{5} \mathrm{H}_{4}-\mathrm{Mn}(\mathrm{CO})_{3}$ were purchased from SigmaAldrich. $\mathrm{CpFe}$ (dppe)I was prepared according a previous reported method. ${ }^{36}$ Thermogravimetric analysis (TGA) and differential scanning calorimetry (DSC) measurements were performed on a Mettler TA 4000 instrument and Mettler DSC 300 differential scanning calorimeter, respectively. The polymer mixtures samples were heated at a rate of $10{ }^{\circ} \mathrm{C} / \mathrm{min}$ from ambient temperature to $800^{\circ} \mathrm{C}$ under a constant flow of nitrogen.X-ray diffraction (XRD) was carried out at room temperature on a Siemens D-5000 diffractometer with $\theta-2 \theta$ geometry. The XRD data was collected using $\mathrm{Cu}-\mathrm{K} \alpha$ radiation $(40 \mathrm{kV}$ and $30 \mathrm{~mA}$ ). SEM photographs were taken with a Philips EM 300 microscope. EDAX (energy dispersive X-ray analysis) microanalysis was performed on a NORAN Instrument micro-probe attached to a JEOL 5410 scanning electron microscope. TEM analysis was conducted on a JEOLSX100 transmission microscope. The finely powered samples were dispersed in $n$-hexane and dropped on a conventional holey carbon copper grid and dried under a lamp.

\section{Preparation of the organometallic precursors}

Preparation of $\left[\mathrm{CH}_{2} \mathrm{CH}\left(\mathrm{C}_{6} \mathrm{H}_{5}\right)\right]_{0,1}\left[\mathrm{CH}_{2} \mathrm{CH}\left(\mathrm{C}_{5} \mathrm{H}_{4} \mathrm{~N} \cdot \mathrm{W}(\mathrm{CO})_{4}\right]_{0.9}\right.$ (1):

To a solution of $\mathrm{W}(\mathrm{CO})_{5} \mathrm{MeOH}$ generated photochemically (from $\mathrm{W}(\mathrm{CO})_{6}$ $0,65 \mathrm{~g}, 1.86 \mathrm{mmol})$ in $\mathrm{MeOH}(75 \mathrm{ml}) 0.178 \mathrm{~g}, 9.17 \mathrm{mmol}$ of the polymer was added and the mixture stirred for $2.5 \mathrm{~h}$. The solution was evaporated under reduced pressure and the solid washed with n-hexane and diethylether. The resulting yellow solid was dried under vacuum at room temperature.Yield 67\%. Anal. Calc for $\mathrm{C}_{9} . \mathrm{H}_{71} \mathrm{~N}_{9} \mathrm{O}_{252} \mathrm{~W}_{063}, \mathrm{C}, \mathrm{H}, \mathrm{N}$ Calc: $\mathrm{C} 37.9 \% ; \mathrm{H} 2.33$ $\%$; N $5.10 \%$. Found C $38.55 \%, \mathrm{H} 3.32 \%, \mathrm{~N} 4.19 \%$. IR $\left(\mathrm{KBr}\right.$ pellet, $\left.\mathrm{cm}^{-1}\right)$ $3089 \mathrm{~m}, 2927 \mathrm{~m}, \quad v(\mathrm{CO}) 2071 \mathrm{vw}, 1974 \mathrm{w}, 1926 \mathrm{vs}$, (py coordinated) $1637 \mathrm{~s}$, $1602 \mathrm{~s}, 1557 \mathrm{w}, 1503 \mathrm{~m}, 1452 \mathrm{w}, 1418 \mathrm{~m}, 1221 \mathrm{w}, 1097$,vw 1068vw, 976s, 959s, $893 \mathrm{~s}, 812 \mathrm{vs}$. ${ }_{n}(2)$ :

Preparation of $\left\{\left[\mathrm{CH}_{2} \mathrm{CH}\left(\mathrm{C}_{6} \mathrm{H}_{5}\right)\right]_{0.1}\left[\mathrm{CH}_{2} \mathrm{CH}\left(\mathrm{C}_{5} \mathrm{H}_{4} \mathrm{~N} \bullet \mathrm{CpRu}\left(\mathrm{PPh}_{3}\right)_{2}\right)\left\{\mathrm{PF}_{6}\right\}\right]_{0.9}\right\}$

To a solution of $\mathrm{CpRu}\left(\mathrm{PPh}_{3}\right)_{2} \mathrm{Cl}(0,55 \mathrm{~g}, 0.758 \mathrm{mmol})$ in $\mathrm{CH}_{2} \mathrm{Cl}_{2}(75 \mathrm{ml})$ $0.073 \mathrm{~g}, 0.69 \mathrm{mmol}$ of the polymer, were added in presence of $\mathrm{NH}_{4} \mathrm{PF}_{6}(0.18$ $\mathrm{g}$ ) and the mixture stirred for $3 \mathrm{~h}$. The solution was evaporated under vaccum and the solution extracted with dichloromethane and concentrated to $30 \mathrm{ml}$. Addition of a mixture of diethylether/n-hexane gives yellow-brown solid. Yield $12 \%$.

IR (KBr pellet, $\left.\mathrm{cm}^{-1}\right) 3045 \mathrm{~m}, 2932 \mathrm{~m}$, (py coordinated) 1616s, 1475w, $1451 \mathrm{~m}, 1432 \mathrm{w}, 1160 \mathrm{w}, 1120 \mathrm{~m}, 1097$,vw 1088vw, 9945s, $836 \mathrm{vs}, 721 \mathrm{vs}$, $694 \mathrm{~s}, 558 \mathrm{~m}, 535 \mathrm{~m}, 518$.

Preparation of $\left\{\left[\mathrm{CH}_{2} \mathrm{CH}\left(\mathrm{C}_{6} \mathrm{H}_{5}\right)\right]_{01}\left[\mathrm{CH}_{2} \mathrm{CH}\left(\mathrm{C}_{5} \mathrm{H}_{4} \mathrm{~N} \cdot \mathrm{CpFe}(\mathrm{dppe})\left(\mathrm{PF}_{6}\right)\right]_{00}\right\}_{0}\right.$ (3):

To a solution of $\mathrm{CpFe}$ (dppe)I $(0,60 \mathrm{~g}, 0.929 \mathrm{mmol})$ in $\mathrm{CH}_{2} \mathrm{Cl}_{2}(80 \mathrm{ml})$ $0.082 \mathrm{~g}, 0.77 \mathrm{mmol}$ of the polymer were added, in presence of $\operatorname{TlPF}_{6}(0.32 \mathrm{~g}$.) and the mixture stirred for $18 \mathrm{~h}$. The solution was filtered through Celite and the resulting red solution was concentrated to $30 \mathrm{ml}$. Addition of a mixture of diethylether/n-hexane gives a yellow-brown solid. Yield $15 \%$.

IR ( $\mathrm{KBr}$ pellet, $\left.\mathrm{cm}^{-1}\right) 3054 \mathrm{~m}, 2924 \mathrm{~m}$, (py coordinated) 1608s, 1455w, $1436 \mathrm{~m}, 1181 \mathrm{~m}, 1169 \mathrm{w}, 1120 \mathrm{~m}, 1097$, vw $1088 \mathrm{vw}, 999.5 \mathrm{~s}, 844 \mathrm{vs}, 743 \mathrm{vs}$, $691 \mathrm{~s}, 557 \mathrm{~m}, 524 \mathrm{~m}$.

Preparation of $\left\{\left[\mathrm{CH}_{2} \mathrm{CH}\left(\mathrm{C}_{6} \mathrm{H}_{5}\right)\right]_{01}\left[\mathrm{CH}_{2} \mathrm{CH}\left(\mathrm{C}_{5} \mathrm{H}_{4} \mathrm{~N} \cdot \mathrm{Cp}_{2} \mathrm{TiCl}\right)\left(\mathrm{PF}_{6}\right)\right]_{00}\right\}_{n}$ (4): To a solution of $\mathrm{Cp}_{2} \mathrm{TiCl}_{2}(0,58 \mathrm{~g}, 2.33 \mathrm{mmol})$ in $\mathrm{CH}_{2} \mathrm{Cl}_{2}(80 \mathrm{ml} 0.233 \mathrm{~g}$, $3.36 \mathrm{mmol}$ of the polymer, in presence of $\mathrm{NH}_{4} \mathrm{PF}_{6}(0.57 \mathrm{~g})$ were added and the mixture stirred for $3 \mathrm{~h}$. The solution was evaporated under vaccum and the red solution extracted with dichloromethane and concentrated to $30 \mathrm{ml}$. Addition of a mixture of diethylether $/ \mathrm{n}$-hexane gives a red solid. Yield $23 \%$.

IR ( $\mathrm{KBr}$ pellet, $\mathrm{cm}^{-1}$ ) 2962m, (py coordinated) $1637 \mathrm{~m}, 1508 \mathrm{w}, 1448 \mathrm{~m}$, $1252 \mathrm{~s}, 1049 \mathrm{vs}, 847 \mathrm{vs}, 558 \mathrm{~m}, 535 \mathrm{~m}, 400 \mathrm{~m}$

Preparation of $\left\{\left[\mathrm{CH}_{2} \mathrm{CH}\left(\mathrm{C}_{6} \mathrm{H}_{5}\right)\right]_{0.1}\left[\mathrm{CH}_{2} \mathrm{CH}\left(\mathrm{C}_{5} \mathrm{H}_{4} \mathrm{~N} \cdot \mathrm{CH}_{3}-\mathrm{C}_{5} \mathrm{H}_{4}-\right.\right.\right.$ $\left.\left.\mathrm{Mn}(\mathrm{CO})_{2}\right]_{0.9}\right\}_{n}(\mathbf{5})$ :

To a solution of $\mathrm{CH}_{3}-\mathrm{C}_{5} \mathrm{H}_{4}-\mathrm{Mn}(\mathrm{CO})_{2}$ THF generated photochemically (from $\left.\mathrm{CH}_{3}-\mathrm{C}_{5} \mathrm{H}_{4}-\mathrm{Mn}(\mathrm{CO})_{3} ; 0,45 \mathrm{~g}, 1.74 \mathrm{mmol}\right)$ in THF $(75 \mathrm{ml}) 0.164 \mathrm{~g}, 1.55 \mathrm{mmol}$ of the polymer were added and the mixture stirred for $2.5 \mathrm{~h}$. The orange-red solution was filtered of and the solution evaporated under reduced pressure. The resulting dark-red solid was dissolved in $\mathrm{CH}_{2} \mathrm{Cl}_{2}$ and filtered through Celite. The solvent was evaporated from filtrate and the solid washed with n-hexane. The solid was somewhat unstable in solution and not re-dissoluble.
The solid was washed with n-hexane and diethylether. The resulting yellow solid was dried under vacuum at room temperature. Yield $32 \%$.

IR $\left(\mathrm{KBr}\right.$ pellet, $\left.\mathrm{cm}^{-1}\right) 3029 \mathrm{~m}, 2924 \mathrm{~m}, v(\mathrm{CO}) 1947 \mathrm{w}, 1855 \mathrm{~s}$, (py coordinated) 1600s, 1419s, 1221w, 1120w, 1068w, 1003w, 823vs, 761s, 700 w, $561 \mathrm{~m}$.

\section{Pyrolysis}

The pyrolysis experiments were carried out, as previously reported, ${ }^{30-39}$ by pouring a weighed portion $(0.05-0.15 \mathrm{~g})$ of the respective precursor on aluminum oxide boats placed in a box furnace, heated from 25 to $300{ }^{\circ} \mathrm{C}$ and then to $800{ }^{\circ} \mathrm{C}$, and annealed for $2 \mathrm{~h}$. The pyrolytic products were characterized by X-ray diffraction (XRD), scanning electron microscopy (SEM), transmission electron microscopy (TEM), energy dispersive X-ray scattering (EDX) and infrared spectroscopy (IR).

\section{RESULTADOS AND DISCUSSION}

Macromolecular complexes 1-5 are insoluble solids. Elemental analysis only gave good values for compound 1, indicating $100 \%$ coordination of the fragment in the polymer chain. For the other compounds were poor analytical results indicating incomplete combustion and / or a lower degree of coordination that $100 \%$.

Polyphosphazenes containing the organometallic fragments : $\mathrm{W}(\mathrm{CO})_{5}$ , $\mathrm{CpRu}\left(\mathrm{PPh}_{3}\right)_{2}, \mathrm{CpFe}$ (dppe), $\mathrm{Cp}_{2} \mathrm{TiCl}$ and $\mathrm{CH}_{3}-\mathrm{C}_{5} \mathrm{H}_{4}-\mathrm{Mn}(\mathrm{CO})_{2}$ anchored to their polymeric chain have been reported previously ${ }^{30-37}$. Coordination of the organometallic fragments to polymeric pyridine chain, can be evidenced by the typical emergence of a new band centered at $1600 \mathrm{~cm}-1$ characteristic of pyridine coordination ${ }^{33}$. On the other hand the presence of the fragments $\mathrm{W}(\mathrm{CO})_{5}$ and $\mathrm{CH}_{3}-\mathrm{C}_{5} \mathrm{H}_{4}-\mathrm{Mn}(\mathrm{CO})_{2}$ in the polymeric chain can be evidenced by the presence of the $v(\mathrm{CO})$ stretching bands of the carbonyls groups of the $\mathrm{W}(\mathrm{CO})_{5}$ and $\mathrm{Mn}(\mathrm{CO})_{2}$ moieties ${ }^{37}$. Some IR bands data of the precursors are summarized in Table 1. The compounds are in general insoluble which preclude an additional solution characterization. TG/DSC characterization was made and discussed as follow.

Table 1 Selected Infrared data for the macromolecular precursor 1-5.

\begin{tabular}{|c|c|c|c|c|}
\hline Precursor & $v(\mathrm{py})$ & $v(\mathrm{CO})$ & $v\left(\mathrm{C}_{5} \mathrm{H}_{5}\right)$ & $v\left(\mathrm{PF}_{6}\right)$ \\
\hline$(1)$ & 1604 & $\begin{array}{c}2071,1974, \\
1926\end{array}$ & & \\
\hline$(2)$ & 1616 & & 1088 & 836 \\
\hline$(3)$ & 1609 & & 1098 & 844 \\
\hline$(4)$ & 1637 & & 1049 & 847 \\
\hline$(5)$ & 1600 & 1947,1855 & & \\
\hline
\end{tabular}

The residual mass of the precursors 1-5 was investigated by TG analysis. A representative TG curve for precursor 1 is shown in figure 2 .

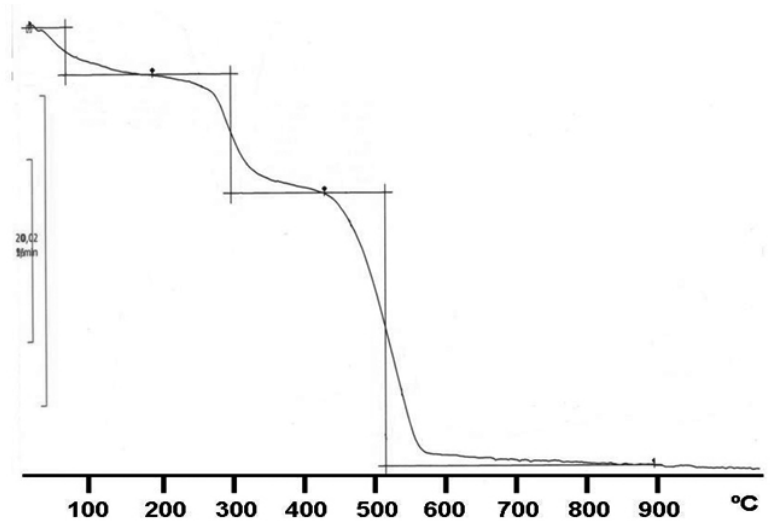

Figure 2: TG curve for the precursor $\left\{\left[\mathrm{CH}_{2} \mathrm{CH}\left(\mathrm{C}_{6} \mathrm{H}_{5}\right)\right]_{0.1}\left[\mathrm{CH}_{2} \mathrm{CH}\left(\mathrm{C}_{5} \mathrm{H}_{4} \mathrm{~N}\right.\right.\right.$ -W(CO) $\left.\left.]_{5}\right]_{0.9}\right\}_{\mathrm{n}}$ 
The curve exhibits a primary mass loss around $311{ }^{\circ} \mathrm{C}$ which can be attributed to the oxidation of the organic matter. ${ }^{30-39}$ The previous smaller weight loss around $80^{\circ} \mathrm{C}$ can be assigned to the loss of residual solvent molecules. A strong weight loss at $526^{\circ} \mathrm{C}$ can be assigned to loss of the $\mathrm{CO}$ groups from the $\mathrm{W}(\mathrm{CO})_{5}$ moiety, calculated $31.8 \%$ and found $29.9 \%$. In agreement with this, exothermic peaks were observed in the DSC curve at $303{ }^{\circ} \mathrm{C}, 458{ }^{\circ} \mathrm{C}$ and 514 ${ }^{\circ} \mathrm{C}$, see Electronic supplementary materials $\mathrm{S}_{1}$. The exothermic peak at 458 ${ }^{\circ} \mathrm{C}$ can be attributed to the carbonization of the organic matter. ${ }^{30-39}$ The final mass residue was $52.7 \%$ which is in approximate agree with the calculated for the formation of $\mathrm{WO}_{3}, 58.39 \%$. The small difference can be due to a small amount of carbon arise from the incomplete combustion of the precursor (1). ${ }^{37}$ For the other precursors a similar TG/DSC behavior holds (See table 1 of Electronic supplementary materials, $\mathrm{S}_{2}$ which summarizes the data for the other precursors). Pyrolytic residues, in general, are in agreement with the respective formulation of the product, ie. the metal oxides $\mathrm{WO}_{3}, \mathrm{RuO}_{2}, \mathrm{TiO}_{2}, \mathrm{Mn}_{2} \mathrm{O}_{3}$ and the iron (III) phosphate $\mathrm{FePO}_{4}$

Main products of pyrolysis from the precursors 1-5 were identified by $\mathrm{X}$-ray diffraction. In Table 2 the composition of the products are summarized along with some morphological as well as size characteristics.

Table 2 Summary of the morphology and particle size data for the pyrolytic products from precursors 1-5.

\begin{tabular}{|c|c|c|c|}
\hline Precursor & Product & Morphology & Particle size (nm) \\
\hline$(1)$ & $\mathrm{WO}_{3}$ & Grains fused & $200-600$ \\
\hline$(2)$ & $\mathrm{RuO}_{2}$ & porous & $60-100$ \\
\hline$(3)$ & $\mathrm{FePO}_{4}$ & Grains joined & 50 \\
\hline$(4)$ & $\mathrm{TiO}_{2}$ & dense & Agglomerates \\
\hline$(5)$ & $\mathrm{Mn}_{2} \mathrm{O}_{3}$ & porous & 200 \\
\hline
\end{tabular}

A detailed discussion of the pyrolytic materials from each of the precursors is given below.

$\left\{\left[\mathrm{CH}_{2} \mathrm{CH}\left(\mathrm{C}_{6} \mathrm{H}_{5}\right)\right]_{0.1}\left[\mathrm{CH}_{2} \mathrm{CH}\left(\mathrm{C}_{5} \mathrm{H}_{4} \mathrm{~N} \cdot \mathrm{W}(\mathrm{CO})_{5}\right]_{0.9}\right\}_{\mathrm{n}}(\mathbf{1})\right.$

Pyrolysis of precursor (1) under air and at $800{ }^{\circ} \mathrm{C}$ affords pure $\mathrm{WO}_{3}$. The XRD shown in figure 1a, exhibits clearly the pattern of $\mathrm{WO}_{3}$. The main peaks corresponding to (002), (020), (200), (202), (120), (112) and (400) of monoclinic $\mathrm{WO}_{3}$ (ICDD Card Nr01-083-pure phase 09509) are clearly observed as is shown in figure 3 a. The less intense peaks -for reason of claritywere not indicated in the figure, but all can be indexed to $\mathrm{WO}_{3}$ phase. Few pure $\mathrm{WO}_{3}$ phases have been reported. $\mathrm{Lu}$ reported a nearly pure monoclinic $\mathrm{WO}_{3}$ from calcinations of $\mathrm{H}_{2} \mathrm{WO}_{4}$ at $500{ }^{\circ} \mathrm{C}^{40}$ with a similar X-ray diffraction to that is shown in figure 3a. Monoclinic $\mathrm{WO}_{3}$ was also obtained by an arc discharge method from W. ${ }^{41}$

Morphology analysis by SEM (see Fig. 3b) evidences a fused-grain material. EDS analysis exhibits the expected presence of $\mathrm{W}$ and $\mathrm{O}$, see figure $3 c$. TEM image indicates an agglomeration of clusters of $\mathrm{WO}_{3}$ nanoparticle with sizes around $200 \mathrm{~nm}$ for the smaller species and $600 \mathrm{~nm}$ for the larger ones see figure $3 \mathrm{~d}$.

$\left\{\left[\mathrm{CH}_{2} \mathrm{CH}\left(\mathrm{C}_{6} \mathrm{H}_{5}\right)\right]_{0.1}\left[\mathrm{CH}_{2} \mathrm{CH}\left(\mathrm{C}_{5} \mathrm{H}_{4} \mathrm{~N} \bullet \mathrm{CpRu}\left(\mathrm{PPh}_{3}\right)_{2}\right)\left\{\mathrm{PF}_{6}\right\}\right]_{0.9}\right\}_{\mathrm{n}}(2)$

Pyrolysis of this precursor affords a XRD consistent with the presence of the tetragonal $\mathrm{RuO}_{2}$ phase. The main two typical (110) and (101) diffraction peaks corresponding to tetragonal $\mathrm{RuO}_{2}$ were observed, ${ }^{42-44}$ as is shown in figure 4a. The enhancing of the (101) orientation, respect to the bulk material is consistent with the presence of nanostructured domains. ${ }^{42}$
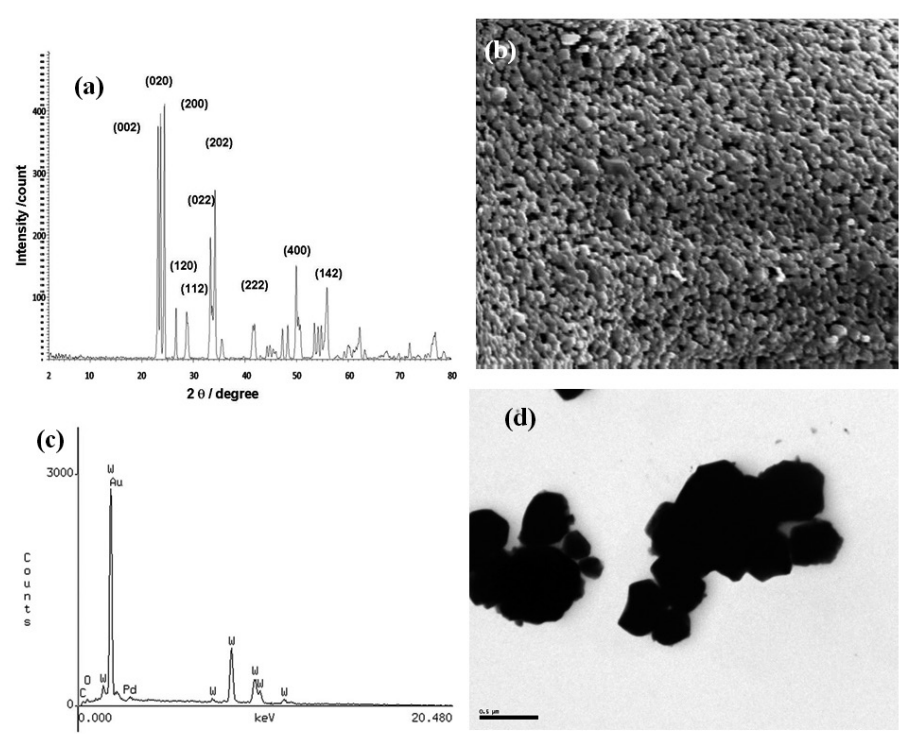

Figure 3: XRD (a) SEM image $(1 \mathrm{~cm}=10 \mathrm{~nm})(\mathrm{b})$, EDS (c) and TEM image (d) of the pyrolytic product from precursor (1).
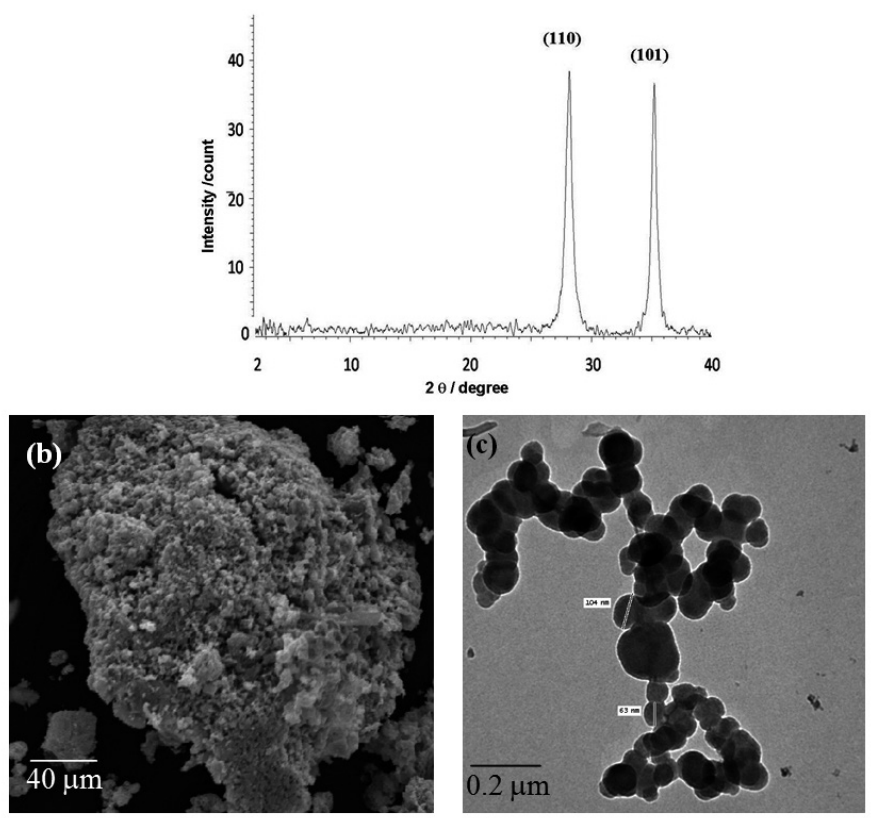

Figure 4: XRD (a), SEM image (b) and TEM image (c) of pyrolytic product from precursor (2).

Although the macromolecular precursor contains phosphorus from the triphenylphosphine ligand, no metallic phosphates were observed after their pyrolysis.

SEM of the thus obtained $\mathrm{RuO}_{2}$ exhibits a porous morphology as shown in figure $4 \mathrm{~b}$. On the other hand, TEM image exhibits a linear arrangement of nearly circular nanoparticles with size in the range $100-60 \mathrm{~nm}$ as is shown in figure 4c. Nanostructured $\mathrm{RuO}_{2}$ exhibits interesting properties such as low resistivity, high chemical and thermodynamic stability under electrochemical environment. The most known application of $\mathrm{RuO}_{2}$ is as an electrode in energy storage electrochemical supercapacitors. ${ }^{42-44}$

$\left\{\left[\mathrm{CH}_{2} \mathrm{CH}\left(\mathrm{C}_{6} \mathrm{H}_{5}\right)\right]_{01}\left[\mathrm{CH}_{2} \mathrm{CH}\left(\mathrm{C}_{5} \mathrm{H}_{4} \mathrm{~N} \cdot \mathrm{CpFe}(\mathrm{dppe})\left(\mathrm{PF}_{6}\right)\right]_{00}\right\}_{n}\right.$ (3)

Pyrolysis of precursor (3) affords nanostructured $\mathrm{FePO}_{4}$ as can be observed from figure $5 \mathrm{a}$, and further confirmed from the characteristics Bragg diffraction peaks, (100), (012), (104), (112) corresponding to hexagonal $\mathrm{FePO}_{4}{ }^{45-49}$. Minor intensity peaks can be due to traces of unidentified Fe phases. The formation 
of $\mathrm{FePO}_{4}$ and the absence of pure iron oxides arises from the presence of $\mathrm{P}$ in the ligand dppe. ${ }^{26}$

SEM images indicate a porous 3-D network as is shown in figure $5 \mathrm{~b}$. The EDAX confirmed the presence of $\mathrm{Fe}, \mathrm{P}$ and $\mathrm{O}$ atoms as is shown in figure $5 \mathrm{c}$. The TEM images (Fig. 5d) evidence the presence of agglomerates composed of nanoparticles with various shapes and sizes.
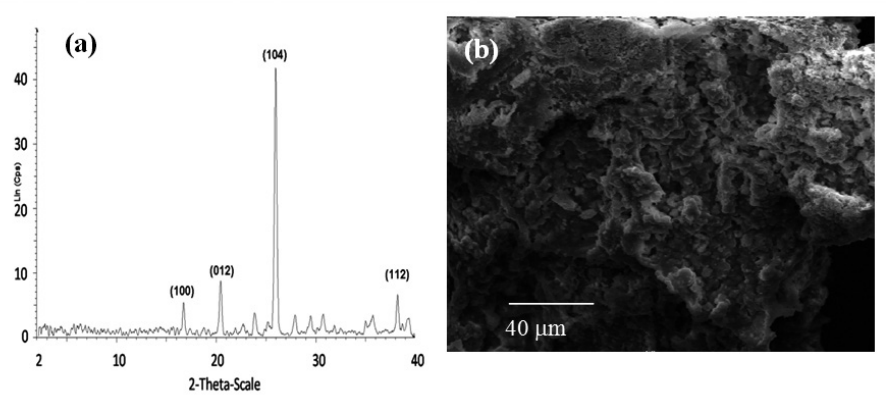

(c)
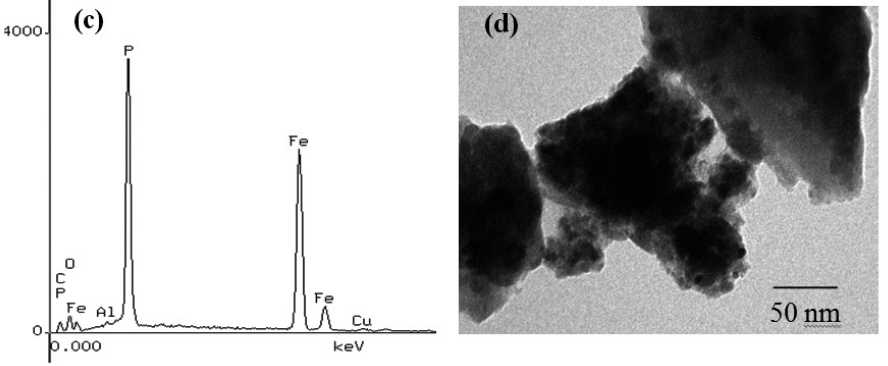

Figure 5: XRD (a), SEM image (b) EDS (c) and TEM image (d) of pyrolytic product from precursor (3).

$\mathrm{FePO}_{4}$ is an interesting material due to its use in catalysis, waste water purification systems, ferroelectrics and lithium batteries. ${ }^{45-48}$

Most typical preparation methods for nanostructured $\mathrm{FePO}_{4}$ involved coprecipitation ${ }^{46}$ by a solvothermal approach using dodecyl sulfate as template ${ }^{47}$ and using microwave irradiation to a solution containing $\left(\mathrm{NH}_{4}\right)_{2} \mathrm{Fe}\left(\mathrm{SO}_{4}\right)_{2} \cdot 6 \mathrm{H}_{2} \mathrm{O}$ and $\mathrm{H}_{3} \mathrm{PO}_{4}$ in presence of $\mathrm{CTAB}$ as stabilizer. ${ }^{49}$ All of these methods are in solution and no solid-state methods to obtain these types of $\mathrm{Fe}$ nanoparticles have been reported.

$\left\{\left[\mathrm{CH}_{2} \mathrm{CH}\left(\mathrm{C}_{6} \mathrm{H}_{5}\right)\right]_{0.1}\left[\mathrm{CH}_{2} \mathrm{CH}\left(\mathrm{C}_{5} \mathrm{H}_{4} \mathrm{~N} \cdot \mathrm{Cp}_{2} \mathrm{TiCl}\right)\left(\mathrm{PF}_{6}\right)\right]_{0.9}\right\}_{n}$ (4)

For the pyrolytic products of precursor of 4 , the (101), (103), (004), (112), (200), (105), (211) diffraction lines, which are characteristic of anatase-TiO, were observed, see Electronic supporting information $\mathrm{S}_{3}{ }^{50-53}$ No significant amounts of other $\mathrm{TiO}_{2}$ brookite or rutile ${ }^{49}$ phases were found. However, some residuals from another $\mathrm{Ti} \mathrm{O}$ might be present as previously observed in other $\mathrm{TiO}_{2}$ preparations. ${ }^{5}$

The morphology analysis by SEM exhibits a dense shape. The TEM images indicate the presence of only some big agglomerates. Despite several preparation methods of nanostructured $\mathrm{TiO}_{2}$ have been reported ${ }^{50-53}$ few solid state routes are known. ${ }^{36}$ Titania nanocrystals have received great attention in recent years for their extensive applications in conventional catalyst support, optics, cosmetics and solar cells. ${ }^{50-53}$ Most of these applications require their direct incorporation into solid-state devices

$\left\{\left[\mathrm{CH}_{2} \mathrm{CH}\left(\mathrm{C}_{6} \mathrm{H}_{5}\right)\right]_{0.1}\left[\mathrm{CH}_{2} \mathrm{CH}\left(\mathrm{C}_{5} \mathrm{H}_{4} \mathrm{~N} \bullet \mathrm{CH}_{3}-\mathrm{C}_{5} \mathrm{H}_{4}-\mathrm{Mn}(\mathrm{CO})_{2}\right]_{0.9}\right\}_{n}(5)\right.$

The pyrolytic product exhibits the typical XRD diffraction peaks of cubic $\mathrm{Mn}_{2} \mathrm{O}_{3}$ at $2 \theta=(211),(222),(321)$ and (400) [54-56], see figure 6a. Minor intensity peaks can be due to traces of unidentified Mn phases The morphology analysis by SEM exhibits a 3-D grain network as is shown in figure 6b. EDS analysis confirms the presence of $\mathrm{Mn}$ and $\mathrm{O}$, see figure $6 \mathrm{c}$.

The TEM images show a diverse arrangement of near circular nanoparticles joined in various shapes and showing a broad range of sizes as is shown in figure $6 \mathrm{~d}$.
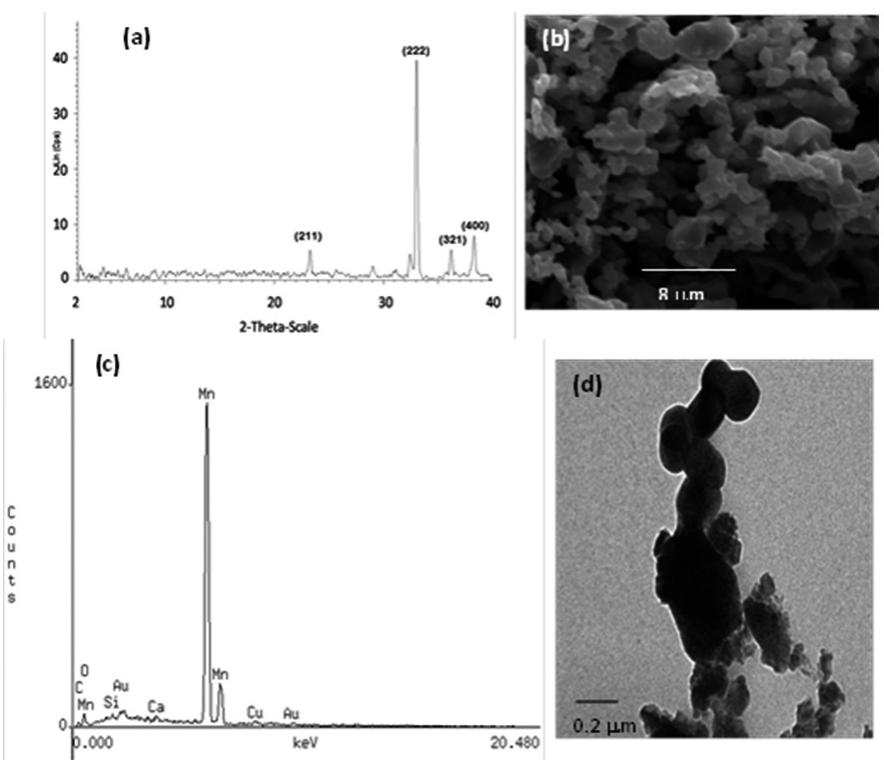

Figure 6: XRD (a), SEM image (b) EDS (c) and TEM image (d) of pyrolytic product from precursor (5).

$\mathrm{Mn}_{2} \mathrm{O}_{3}$ constitutes an interesting target due to potential applications as catalyst for carbon monoxide removing, ${ }^{54}$ for the preparation of soft magnetic materials ${ }^{54}$ and as constituent of electrode materials for rechargeable lithium batteries. ${ }^{56}$ The main preparation methods involve the reaction of aqueous solution of $\mathrm{MnCO}_{3}$ with $\mathrm{KMnO}_{4}{ }^{54}$ decomposition of the manganese coordination polymer $\left[\mathrm{Mn}(\mathrm{Pht})\left(\mathrm{H}_{2} \mathrm{O}\right)\right]_{\mathrm{n}}$ in presence of oleic acid triphenylphosphine as stabilizer and capping ${ }^{55}$ and using hydrothermal method starting from $\mathrm{MnO}_{2}{ }^{56} \mathrm{However}$, no solid-state method to prepare nanoparticles of $\mathrm{Mn}_{2} \mathrm{O}_{3}$ have been reported.

\section{Pyrolysis mechanism}

The probable formation mechanism of $\mathrm{WO}_{3}, \mathrm{RuO}_{2}, \mathrm{TiO}_{2}, \mathrm{Mn}_{2} \mathrm{O}_{3}$ and the iron (III) phosphate $\mathrm{FePO}$ nanoscale materials described here involves the cross-linking ${ }^{36}$ of the PSP-co-4-PVP chains by the organometallic metal centers during the initial annealing step, followed by the carbonization of the organic matter to produce holes where the metal centers begin to coarsen and grow. ${ }^{57}$ Carbonization of the organic matter usually occurs in the pyrolysis of metallic and organometallic derivatives of polymers around $350{ }^{\circ} \mathrm{C} .{ }^{57}$ Additionally, some incomplete degree of carbonization can produce a carbon host ${ }^{57}$ where the nanoparticles are subsequently stabilized in solid state. This carbon matrix formed during this solid state synthetic method constitutes the analogue of the stabilization effect exploited in the synthesis of nanoparticles and nanocrystals in solution, which is typically provided by a coordination stabilizer such as TOPO, TOP, alkylamines, alkylthiols and related ligands. ${ }^{58}$

\section{CONCLUSIONS}

Macromolecular organometallic derivatives of poly(styrene-co4vinylpyridine), PS-co-4-PVP, of the general formula: $\left\{\left[\mathrm{CH}_{2} \mathrm{CH}\left(\mathrm{C}_{6} \mathrm{H}_{5}\right)\right]_{0},[\mathrm{C}\right.$ $\left.\left.\mathrm{H}_{2} \mathrm{CH}\left(\mathrm{C}_{5} \mathrm{H}_{4} \mathrm{~N} \cdot \mathrm{ML}_{\mathrm{n}}\right)\right]_{00}\right\}_{n} ; \mathrm{ML}_{\mathrm{n}} \mathrm{W}(\mathrm{CO})_{5}(\mathbf{1}), \mathrm{CpRu}\left(\mathrm{PPh}_{3}\right)_{2}$ (2), $\mathrm{CpFe}(\mathrm{dppe})(\mathbf{3})$, $\mathrm{Cp}_{2} \mathrm{TiCl}^{(4)}$ and $\mathrm{CH}_{3}-\mathrm{C}_{5} \mathrm{H}-\mathrm{Mn}(\mathrm{CO})_{2}(\mathbf{5})$ are useful precursors of the micro and nanostructured materials $\mathrm{WO}_{3}, \mathrm{RuO}_{2}, \mathrm{TiO}_{2}, \mathrm{Mn}_{2} \mathrm{O}_{3}$ and the iron (III) phosphate $\mathrm{FePO}_{4}$ for the case of iron precursor. In general, pure micro and nanostructured oxides can be obtained except when the metallic salt contains phosphorus atoms. In most cases the nanoparticles are somewhat large and in some cases form agglomerates. The smallest particles correspond to $\mathrm{RuO}_{2}$.

The synthesis reported here may constitute a useful and general method to obtain metallic oxides micro and nanoparticles in solid-state. Solid-state methods to produce metallic nanoparticles are necessary to incorporate the particles into solid-state device such as electronic parts, sensors, high temperature catalysts, etc. ${ }^{18,19}$ Thus, the chemical and mechanical stability of these materials are crucial for the fabrication of nanodimensional optoelectronic circuits and optical memory with ultrahigh recording speed and 
storage density. ${ }^{21}$ Experiments to include these micro and nanostructured metal oxide and $\mathrm{FePO}_{4}$ into solid matrix are in course.

\section{ACKNOWLEDGEMENTS}

To Project Fondecyt 1120179 for financial support.

\section{REFERENCES}

1. Z. Zhou, N. Tian, J.T. Li, I. Broadwell, Sh. G. Sun Chem. Soc. Rev. 40, 4167, (2011).

2. R. K. Joshi, J. J. Schneider Chem. Soc. Rev. 41, 5285, (2012).

3. H. Goesmann, C. Feldsmann Angew. Chem. Int. Ed. 49, 1362 (2010).

4. C. Zhang, J. Chen, Y. Zeng, X. Rui, J. Zhu, W. Zhang, Ch. Xu, L. M. Lim, H. H. Hng, Q. Yan Nanoscale 4, 3718, (2012).

5. P. Poizot, L. S. Grugeon, L. Dupont, J. M. Tarascon Nature 407, 496, (2000).

6. Y. Li, A. Somorjai Nano Lett. 10, 289, (2010).

7. F. Bozon-Verduraz, F. Fievet, J. Y. Piquemal, R. Brayner, K. El Kabouss, Y. Soumare, G. Viau, S. Shaffev Braz. J. Phys. 39, 134, (2009).

8. A. Tricoli, M. Righettoni, A. Teleki Angew. Chem. Int. Ed 49, 7632, (2010).

9. P. Kamat J. Phy. Chem. C 116, 11849, (2012).

10. H. Huang, B. Liang, L. Liu, X. Wang, D. Chen, G. Shen J. Mater. Chem. 22, 13428, (2012).

11. J. S. Hu, L. S. Zhong, W. G. Song, L. Wan Adv. Mater. 20, 2977, (2008).

12. C. H. Yan, D. Xue J. Phys. Chem. B 110, 1581, (2006).

13. N. Pinna, M. Niederberger Angew. Chem. Int. Ed. 47, 5292, (2008).

14. M. Fernandez-Garcia, A. Martinez-Arias, J. C. Hanson, J. A. Rodriguez Chem. Rev. 104, 4063, (2004).

15. M. L. Khan, A. Glaria, C. Pages, M. Monge, L. S. Macary, A. Maisonnat, B. J. Chaudret Mat. Chem. 19, 4044, (2009).

16. J. P. Jolivet, S. Cassignon, C. Chanea, D. Chiche, D. Durupthy, D. Portehault, C. R. Chimie, 13, 40, (2010).

17. C. Díaz, M. L. Valenzuela. Metallic Nanostructures using Oligo and Polyphosphazenes as Template or Stabilizer in Solid State (Encyclopedia of Nanoscience and Nanotechnology), Nalwa H.S. Ed, American Scientific Publishers, 239, (2012).

18. G. Walkers, I. P. Parkin Mater. Chem. 19, 574, (2009).

19. M. Meilikhov, K. Yusenko, D. Esken, S. A. Turner, G. Van Tendoloo, R. A. Fische Eur. J. Inorg. Chem. 3701, (2010).

20. B. Teo, X. Sun Chem. Rev. 107, 1454, (2007).

21. G. B. Khomutov, V. V. Kislov, M. N. Antipina, R. V. Gainutdinov, S. P. Gubin, A. Y. Obydenov, S. A. Pavlov, A. A. Rakhnyanskaya, A. N. Sergeev-CherenkovE. S. Soldatov, D. V. Suyatin, A. L. Toltikhina, A. S. Trifonov, T. V. Yurova Microelectronic Engineering 69, 373, (2003).

22. P. Guo, W. Wenyan, G. Liang and P. Yao J. Colloid. Interf. Sci. 323, $229,(2008)$

23. L. A. Belfiore, M. Pat Curdie and E. Ueda Macromolecules 26, 6908, (1993)

24. A. Haynes, P. M. Maitlis, R. Quyoum, C. Pulling, H. Adams, S. E. Spey, and R.W. Strange J. Chem. Soc. Dalton Trans. 2565, (2002).

25. C. V. Franco, M. M. da SilvaPaula, G. Goulart, L. F. De Lima, L. K. Noda and N. S. Goncalves Mater. Letters 60, 2549, (2006).

26. M. Antonietti, E. Wenz, L. Bronstein and M. Seregina, Adv. Mater. 7, $1000,(1995)$

27. F. Wen, W. Zhang, G. Wei, Y. Wang, J. Zhang, M. Zhang and L. Shi Chem. Mater. 20, 2144, (2008)
28. S. Klingelfer, W. Heitz, A. Greiner, S. Oestreich, S. Forster and M. Antoinietti J. Am. Chem. Soc. 119, 10116, (1997).

29. P. Zheng, X. Jiang, X. Zhang L. Shi, Langmuir 22, 9393, (2006).

30. C. Díaz and M.L. Valenzuela J. Chil. Chem. Soc. 50, 417, (2005).

31. C. Díaz, P. Castillo and M. L. Valenzuela J. Cluster. Science 16, 515, (2005).

32. C. Díaz and M. L. Valenzuela J. Inorg. Organomet. Polym. Mater. 16, 123, (2006)

33. C. Díaz and M. L. Valenzuela Macromolecules 39, 103, (2006)

34. C. Díaz and M. L. Valenzuela J. Inorg. Organomet. Polym. Mater.16, 216 , (2006).

35. C. Díaz and M. L. Valenzuela J. Inorg. Organomet. Polym. Mater. 6, 419, (2006).

36. C. Díaz, M. L. Valenzuela, L. Zuñiga, C. O’Dwyer J. Inorg. Organometallic. Polymer 19, 507, (2009).

37. C. Diaz, M. L. Valenzuela, D. Bravo, V. Lavayen and C. O'Dwyer Inorg. Chem. 47, 11561, (2008).

38. C. Díaz, M. L. Valenzuela, E. Spodine, Y. Moreno and O.Peña, J. Cluster Science 18, 831, (2007).

39. C. Díaz, V. Lavayen, C. O’Dwyer J. Solid State Chemistry 183, 1595 , (2010).

40. Z. Lu, S. M. Kanan, C. P. Tripp J. Mater. Chem. 12, 983, (2002).

41. A. A. Ashkarran, A. Iraji, M. M. Ahadian and S. A. Ardakani Nanotechnology 19, 195709, (2008).

42. A. A. Devadas, S. Baranton, T. W. Napporn and Ch. Coutanceau J. Power Sources 196, 4044, (2011).

43. W. Dmowski, T. Egami, K. E. Swide-Lyons, C.T. Love and D. R. Rolison J.Phys. Chem. 106, 12677, (2002).

44. S. Wendt, M. Snapp, H. Over J. Am .Chem. Soc. 126, 1537, (2004).

45. H. Liu J. Nanopart. Res. 12, 2003, (2010).

46. X. Wang, X. Yang, H. Zheng, J. Jin and Z. Zhang J. Cryst. Growth. 274, 214, (2005)

47. D. Yu, J. Qian, N. Xue, D. Zhang, Z. C. Wang, X. Guo, W. Ding and Y, Chen Langmuir 23, 382, (2007).

48. M. Li, Z. Wu, Z. Ma, V. Schwartz, D. R. Mullins, Sh. Dai, S. H. Overbury J. of Catalysis 266, 98, (2009).

49. Y. Yin, H. Zhang, P. Wu, B. Zhou, Ch.Cai Nanotechnology 21, 425504, (2010).

50. D. Coronado, G. Rodriguez-Gattorno, M. Espinosa-Pesqueira, C. Cab de Coss, G. Oskam Nanotechnology 19, 145605, (2008).

51. S. Bakardjieva, V. Stengl, L. Szatmary, J. Subrt, J. Lukac, N. Murafa, D. Niznansky, K. Cizek, J. Jirlovsky, N. Petrova Mater. Chem. 16, 1709, (2006).

52. H. M. Pathan, M. Sun-Ki, J. D. Desai, K. D. Jung, O. S. Joo Materials Chemistry and Physics 97, 5, (2006).

53. S. Perera, N. Zelenski, E: G. Gillan Chem. Mater. 18, 2381, (2006).

54. C. Ji, Y. Zhu, K. Bao, L. Shi, S. Liu, Y. Qian J. Phys. Chem. C 113, 17755 , (2009).

55. M. Salavati-Niasari, F. Mohandes, F. Davar, K. Saberyan Applied Surface Science 256, 1476, (2009).

56. X. Chen, X. Li, Y. Jiang, X. Li Solid State Comm. 136, 94, (2005).

57. C. Díaz, M. L. Valenzuela, V. Lavayen, C. O’Dwyer Inorganic Chemistry 51, 6228, (2012).

58. C. N. Rao, A. Muller, Cheetham (ed) AK, The Chemistry of Nanomaterials, Synthesis, Properties and Applications. Wiley-VCH, Weinheim, (2004). 